\title{
Original paper \\ Prospection for gold and new occurrences of gold-bearing mineralization in the eastern Mongolian Altay
}

\author{
Jaroslav AICHLER ${ }^{1 \dagger}$, Jan MALEC ${ }^{1 *}$, Josef VEČEŘA ${ }^{1}$, Pavel HANŽL'1 , David BURIÁNEK'1, Tamara \\ SIDORINOVÁ', Zdeněk TÁBORSKÝ'1, Khasbar BOLORMAA², Dolgor BYAMBASUREN²
}

\author{
${ }^{1}$ Czech Geological Survey, Klárov 3, 11821 Prague 1, Czech Republic; jan.malec@geology.cz \\ ${ }^{2}$ Geological Investigation Centre, Songino Khayrkhan District, PO Box 37/307; Ulaanbaatar, Mongolia \\ ' deceased \\ ${ }^{*}$ Corresponding author
}

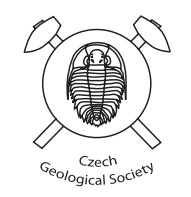

Geological mapping and regional geochemical prospection on a scale of 1:50,000, covered an area of about 4,000 $\mathrm{km}^{2}$ in the Zamtyn Nuruu region of the eastern Mongolian Altay. Northern part of the region is formed by the Lake Zone Terrane, the southern by the Gobi Altay Terrane; these two units are separated by the Bogd fault. The panned-concentrate heavy mineral survey was combined with the dry stream-sediment geochemistry, both being complemented by lithogeochemical sampling.

The dry stream-sediment geochemistry proved to be a suitable method for regional prospection in semiarid to arid areas of Mongolia. The morphology and composition of placer gold grains were studied in order to estimate the distance from the primary source, and to constrain the nature of prospective primary mineral deposits. Based on the results of the regional geochemical survey and geological mapping, follow-up works were focused on prospective areas including the reconnaissance field works, detailed geochemical sampling, and geophysical measurements.

New occurrences and signs of $\mathrm{Au}, \mathrm{Cu}, \mathrm{Zn}$ and $(\mathrm{Ba})-\mathrm{As}-\mathrm{Sb}-\mathrm{Hg}$ mineralizations were discovered. The ascertained goldbearing mineralizations are represented namely by $\mathrm{Au}$ and $\mathrm{Au}-\mathrm{Ag})$ quartz veins in basic metavolcanic rocks of the Neoproterozoic Khan Taishir and volcanic rocks of the Permian Delger Khangay formations. Gold locally accompanies vein-disseminated base metal mineralization in some Proterozoic and Lower Palaeozoic formations. A prospective occurrence of clastic gold in Mesozoic conglomerates and sandstones was found at the northern edge of the Zamtyn Nuruu around the Samoandamba Uul. The geochemical survey has revealed a contrast in occurrence of ore indices between the two terranes formig the studied area. While the Lake Terrane and, especially, the Neoproterozoic Khan Taishir Formation are rich in gold and base metal showings, the Gobi Altay Terrane is barren.

Keywords: geochemical prospecting, gold, Mongolian Altay, Lake Terrane, Khan Taishir Formation

Received: 4 April 2008; accepted 10 June 2008; handling editor: M. Štemprok

\section{Introduction}

The geological survey in the eastern part of the Mongolian Altay was carried out within the framework of project of the International Development Cooperation of the Czech Republic in 2004-2006. The aim of the project was to conduct a comprehensive geological and geochemical mapping on a scale of 1:50,000 covering eleven map sheets, followed by hydrogeological mapping on a scale 1:100,000. An assessment of the mineral potential and a survey of newly found occurrences of ore mineralization, industrial rocks and minerals were additional objectives of the project. All field and laboratory data were compiled and managed using a geographic information system (GIS) (Krejčí and Hanžl 2006). A single occurrence of $\mathrm{Cu}$ mineralization and four nonmetal occurrences were registered in the surveyed area by MRPAM (Mineral Resources and Petroleum Author- ity of Mongolia). In adjacent areas, granite-related ore mineralizations $(\mathrm{Pb}-\mathrm{Zn}, \mathrm{Cu}, \mathrm{Au})$ and $\mathrm{Au}$-mineralization in metamorphosed rocks were recorded as sporadic (Dejidmaa et al. 2001). The results of geochemical survey indicated a number of areas with expected primary ore mineralization. New ore occurrences and ore showings were later studied and documented. Some of them were evaluated as perspective and recommended for a followup exploration.

An overview of geological and prospecting works and data was presented in the final report (Hanžl and Aichler 2007) available in the Geological Information Centre of MRPAM and in the Czech Geological Survey-Geofond. The current paper brings general information about methodology and the results (with a special emphasis on gold mineralization). The background analytical data cannot be shown due to constraints stipulated by the contract with the MRPAM. 


\subsection{Geographic position}

The studied area in SW Mongolia is located along the boundary between the Gov Altay and Bayankhongor Aymags (regions) in the somons (districts) of Chandman, Erdene, Baatsagaan, and Bayantsagaan. The mountain ranges occupy about $60 \%$ of the mapped area and they are represented by the Khar Argalantyn Nuruu in the north, the Zamtyn Nuruu and the Bayan Tsagaan Nuruu in the central part and the Gichigeney Nuruu (with the highest peak Ulaan Ovot Uul reaching an altitude of 3,359 m) in the south. They trend in general NW-SE to W-E, and have steep and rugged slopes often cut by narrow and deep valleys. The mountain ranges are separated from each other by intermountain endorheic depressions filled often by lakes. The largest of them, Boon Tsagaan Nuur, is located in the NE part of studied area in the Valley of Lakes at c. 1,300 $\mathrm{m}$ a.s.1.

This region is arid, especially in intermountain depressions, which do not receive more than $200 \mathrm{~mm}$ of rain in a year. Only parts of the mountain regions can be considered as semiarid with annual precipitation up to $350 \mathrm{~mm}$ (arid: less than $250 \mathrm{~mm}$, semiarid: $250-500$ mm; Nicols 1999).

\section{Geological setting and ore mineraliza- tion}

Central Asia represents a mosaic of microcontinents, collapsed ocean basins, and associated accretionary volcanosedimentary complexes, subduction-related igneous arcs and anorogenic intrusive massifs (Hendrix et al. 1992). Geologically, Mongolia is built by a number of tectonic zones (Dergunov 2001), which form a part of the extensive Central Asian Orogenic Belt (Mossakovsky et al. 1993). This belt developed between the Siberian Block in the N, the Tarim Block in the SW and the Sino-Korean Block in the $\mathrm{S}$ within time span of c. 1000-250 Ma (for review see Windley et al. 2007).

Traditionally, the geological structure of Mongolia is subdivided into the northern and southern domains. The northern domain is considered as a Caledonian orogen with relics of Precambrian rocks, whereas the southern domain is interpreted as a Variscan orogen. The two are separated by the so-called Main Mongolian lineament - a regional topographic and structural boundary separating mostly Precambrian and Lower Palaeozoic rocks in the north from dominantly Middle-Upper Palaeozoic units in the south (Badarch et al. 2002). The surveyed area is situated along the boundary, which separates two different structural zones: the northerly Lake Zone and the southerly Mongolian Altay Zone (Rauzer et al. 1987). The boundary between these zones is formed by a major
E-W oriented fault (Rauzer et al. 1987), which coincides with the western continuation of the recently re-activated Bogd fault (Tapponier and Molnar 1979) known also as the North Gobi Altay fault system (Cunningham et al. 1996).

The Lake Zone corresponds to the Lake Terrane exhibiting an island-arc character and the Mongolian Altay Zone to Gobi Altay Terrane interpreted as a former forearc/backarc (Badarch et al. 2002). Geological outline of the studied area is given in Fig. 1.

\subsection{Geology of the Zamtyn Nuruu area}

The Lake Terrane in the studied area is composed of slightly metamorphosed volcanosedimentary sequences of the Neoproterozoic to Lower Palaeozoic ages, which alternate in tectonic mosaic with highly metamorphosed rocks of the Zamtyn Nuruu and Alag Khadny crystalline complexes and with relics of oceanic crust. The Permian volcanic and volcanoclastic sequences cover the Lower Palaeozoic rocks mainly in the NE and SW parts of the outcrops. These are tectonically incorporated into the structure of the Lake Terrane along its southern boundary.

The Gobi Altay Terrane is represented by the Bayan Tsagaan subzone (Dergunov 2001) built by slightly metamorphosed Lower Palaeozoic volcanoclastic sequences and Devonian-Carboniferous volcanoclastic sediments of a forearc/backarc character (Badarch et al. 2002). Metamorphic rocks are exposed only in tectonic slices along the northern boundary of the Carboniferous Tsokhoriin Nuruu Fm. and along the Bogd fault (Hrdličková et al. this volume). The basement is formed by the Chandman Khayrkhan Crystalline Complex.

Plutonic rocks of the Palaeozoic age in the Lake Terrane include undifferentiated bodies of gabbros and granites in the Zamtyn Nuruu Crystalline Complex, the granitic Burdnii Gol Massif of Cambrian age, and the Permian Shar Oroy Massif built by granites with an alkaline affinity (Hanžl et al. 2007 this volume). The Carboniferous Chandman Massif is formed by intermediate to acid intrusive rocks of the Gobi Altay Terrane (Economos et al. in print).

Following a Late Palaeozoic phase of tectonic consolidation of Central Asia, the ocean-basin closure continued in the Early Mesozoic along the southern margin of the newly enlarged Asian continent (Sengör 1984) and the Palaeozoic-Early Mesozoic tectonic evolution was terminated by a continental collision during the closure of the Mongolsk-Ochotsk marine basin (Dergunov 2001).

In the Zamtyn Nuruu, Mesozoic sequences represented by Upper Jurassic-Lower Cretaceous continental sediments and volcanics developed in a rift regime - in 

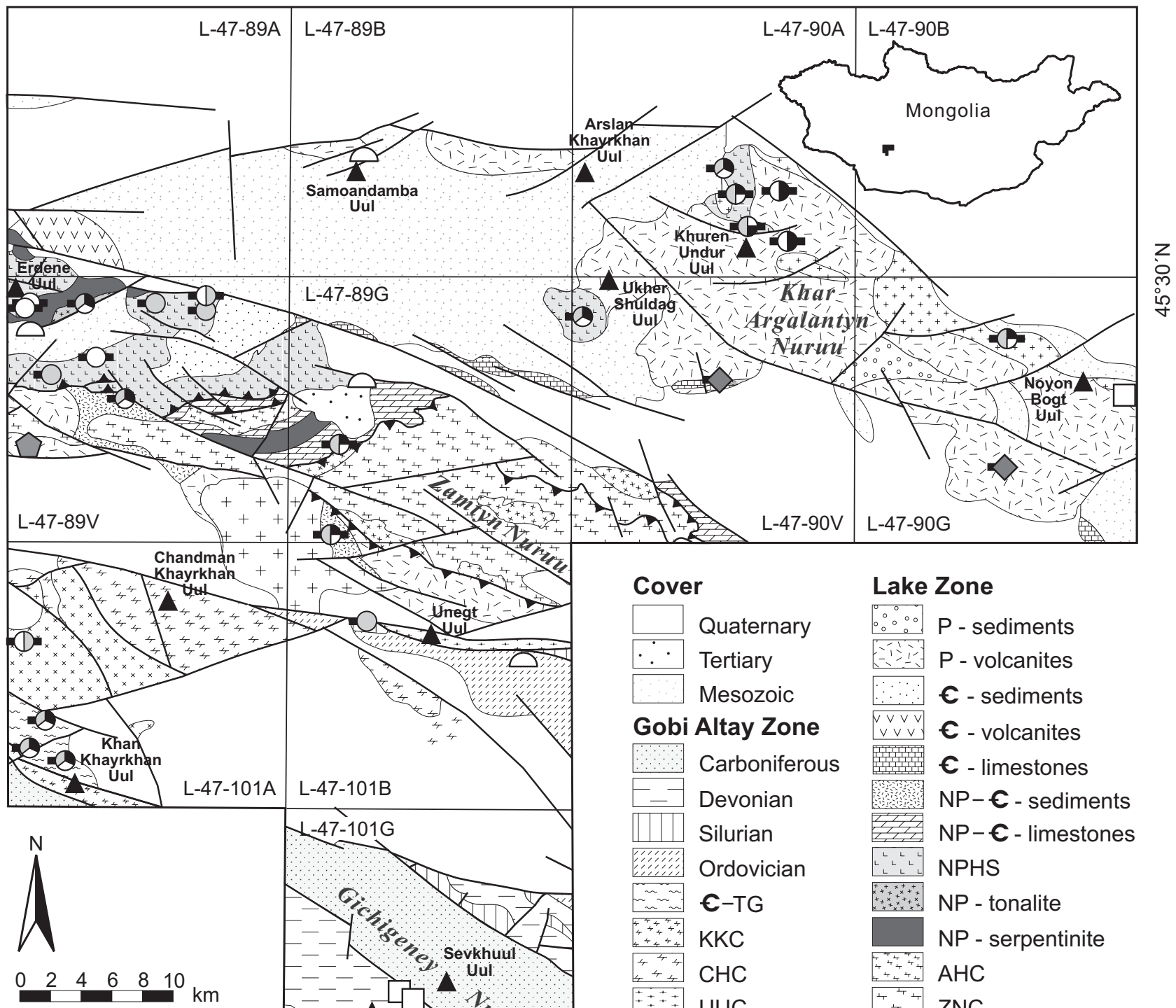

\section{Mineralization types}

In crystalline rocks

- Au quartz vein

-1) $\mathrm{Au}-(\mathrm{Cu}, \mathrm{Ag})$ quartz vein

- Cu-Ag-Au-polymetallic vein-disseminated

(6) Cu-Ag and $\mathrm{Cu}-(\mathrm{Ag}, \mathrm{Au})$ vein

- Cu vein-disseminated

\section{Cover}

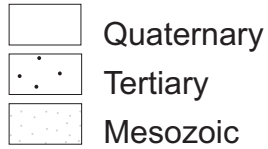

Gobi Altay Zone

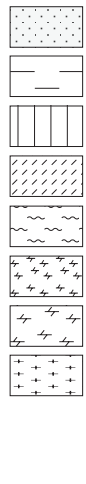

Carboniferous

Devonian

Silurian

Ordovician

C-TG

$\mathrm{KKC}$

$\mathrm{CHC}$

UUC

\section{Lake Zone}

\begin{tabular}{|c|c|}
\hline & P - sediments \\
\hline & P - volcanites \\
\hline & $\boldsymbol{C}$ - sediments \\
\hline & $\boldsymbol{C}$ - volcanites \\
\hline & $\boldsymbol{C}$ - limestones \\
\hline & NP- $€$ - sediments \\
\hline & NP- $\boldsymbol{\epsilon}$ - limestones \\
\hline & NPHS \\
\hline & NP - tonalite \\
\hline & NP - serpentinite \\
\hline & $\mathrm{AHC}$ \\
\hline & \\
\hline
\end{tabular}

\section{Granitoid massifs}

In Permian volcanics

GZNC

- Au-(Ag) quartz vein

(P) Cu-(Au,Ag) vein-disseminated

$\mathrm{GCH}$

GBU

$\diamond$ As-Sb-Hg vein-disseminated

GSO

$\triangle \mathrm{Zn}-(\mathrm{Pb}, \mathrm{As})$ disseminated

Pyrite disseminated

$\frown$ Gold placer

Fig. 1 Geological outline of the studied area in the eastern Mongolian Altay and the main occurrences of ore mineralizations (according to Hanžl and Aichler 2007).

Abbreviations used: TG - Tugrug Fm., NPHS - Khan Taishir Fm.; crystalline complexes: KKC - Khan Khayrkhan, CHC - Chandman Khayrkhan, UUC - Unegt Uul, AHC - Alag Khadny, ZNC - Zamtyn Nuruu; granitoid massifs: GZNC - intrusive rocks of the Zamtyn Nuruu, GCH - Chandman, GBU - Burdnii Gol, GSO - Shar Oroy; NP - Neoproterozoic, $€$ - Cambrian, P - Permian 
the Mesozoic Gobi-Altay rift zone (Yanshin 1976; Yarmolyuk 1983, 1986; Kovalenko et al. 1995). Progressive cessation of tectonic processes initiated throughout the whole Mongolia in the end of the Early Cretaceous, and the Late Cretaceous-Palaeogene saw a period of development similar to a platform evolution (Yanshin 1976). Sediments of this period are not preserved.

The tectonic reactivation of the region was triggered by a collision of the Eurasian Plate with the Indian Subcontinent in the Late Cenozoic, whereby the E-W oriented faults accommodated deformations in the Himalayan region (Tapponier and Molnar 1979). Generally, the studied area has a typical fault-controlled topography, where mountain ranges are separated by intermountain basins. The Neogene-Quaternary detrital sediments filled endorheic intermountain depressions. The area has a very young type of relief as it is supposed for the adjacent Gobi Altay range (Vassallo et al. 2007).

\subsection{Ore mineralization of Zamtyn Nuruu}

In terms of geological units and related mineralization, the Lake Terrane corresponds to Nuuryn metallogenic belt and the Gobi Altay Terrane hosts the Bayangovi metallogenic belt (Dejidmaa and Badarch 2005).

The Nuuryn metallogenic belt hosts the following types of deposits: Cyprus-type $\mathrm{Cu}-\mathrm{Zn}-\mathrm{Ag}-(\mathrm{Au})$ sulphides, iron formation, $\mathrm{Au}$-sulphide quartz veins and stockworks associated with disseminated $\mathrm{Au}, \mathrm{Au}-\mathrm{Cu}$ skarns, W greisens, porphyry $\mathrm{Au}-\mathrm{Cu}, \mathrm{PGE}-$ rich podiform $\mathrm{Cr}$, talccarbonate, gabbroic $\mathrm{Ni}-\mathrm{Cu}$ and Ti-Fe. Mineral deposits of the Lake Terrane were described by Shaandar (2003) who recognized their economic importance.

The Bayangovi metallogenic belt is characterized especially by deposits and occurrences of Au-(carbonate)-quartz veins, $\mathrm{Cu}-\mathrm{Ag}$ quartz veins and stockwork deposits related to regionally metamorphosed rocks and to calc-alkaline granites (Dejidmaa and Badarch 2005). The map of deposits and occurrences of Mongolia on a scale $1: 1,000,000$ together with their description was compiled by Dejidmaa et al. (2001). Dejidmaa et al. (2005) published also a review of mineral deposit models for Mongolia.

\section{Methodology of the geochemical prospecting and exploration for mineral deposits}

The regional geochemical prospection was carried out on eleven sheets of map on the scale 1:50,000. The main objective of regional geochemical study was to reveal potentially mineralized zones, ore-bearing structures and/or mineral deposits. The panned-concentrate survey on a scale of 1:50,000 was used as a basic method for regional geochemical prospection in pre-Quaternary formations and it was combined with the dry stream-sediment survey. These two methods were complemented by whole-rock geochemistry and, optionally, by sampling of lake sediments or soils.

All sampling sites were documented by field photography, magnetic susceptibility measurements and collecting of mineralized and weathered rock materials for laboratory examination.

Reconnaissance field work and detailed prospection were focused to prospective areas determined by regional geochemical survey and geological mapping. Identification of more than twenty potential fields of gold-bearing mineralizations was based on a distinction of heavy-mineral concentrate (HMC) anomalies, element-indicators in stream sediments, on finds of ore occurrences and on recognition of geological settings suitable for ore mineralization. To a various extent, we used a more detailed geochemical sampling, geophysical measurements, reconnaissance tours, and trenching in search for the primary ore mineralization.

\subsection{Panned-concentrate drainage survey}

Samples of c. $15 \mathrm{~kg}$ (10 litres) were taken from wet but mostly dry intermittent river beds in a grid of approx. 1 sample per $2 \mathrm{~km}^{2}$ (or $\sim 1$ sample per $1 \mathrm{~km}^{2}$ in preQuaternary outcrop areas). The sampling frequency was adjusted to the geological situation, geomorphology and drainage pattern. A denser sampling pattern was appropriate in a rugged terrain with well-developed drainage pattern and in geologically complex and/or perspective areas. Lower sampling density was employed in a flat relief with a thick sedimentary cover. Large intermountain depressions filled with Quaternary sediments were not sampled at all. The HMC samples were sieved when wet (mesh size $2 \mathrm{~mm}$ ) and hand-panned to obtain a grey concentrate. Semiquantitative mineralogical analyses of 2.5 thousand HMC samples were carried out in the laboratory of the Geological Research Centre in Ulaanbaatar. The following heavy minerals were identified (according to their importance for ore-prospection): gold, pyrite, chalcopyrite, galena, malachite, azurite, metal copper, metal lead, secondary lead minerals, bismutite, scheelite, cassiterite, molybdenite, barite, fluorite, magnetite, ilmenite, chromite, Mn-minerals, a Ta-Nb mineral, xenotime, monazite, zircon, radioactive zircon, apatite, titanite, rutile, anatase, leucoxene, kyanite, sillimanite, andalusite, and spinel. The results of HMC analyses were stored in ESRI personal geodatabase. Two sets of distribution maps were compiled and plotted using the ArcGIS software on 
a scale 1:50,000 including possible source areas of gold and selected heavy minerals (see examples of maps on http://www.geology.cz/mongolia).

\subsection{Stream-sediment survey}

Stream-sediment geochemistry was found to be an efficient method for outlining potentially mineralized areas. Finer (silt) fractions of alluvial sediments represent well the geochemistry of the drainage pattern and also reduce a "nugget effect" during sampling (Fletcher 1997). This method can be effectively used also in regional prospection for gold as shown by Xie and Wang (1991).

In streams with a low silt fraction, a modified method of sampling was employed. Composite samples collected along a stream were sieved in the field to obtain about 6 $\mathrm{kg}$ of the fraction under $2 \mathrm{~mm}$. The density of sampling was approximately 1 sample per $2 \mathrm{~km}^{2}$ for pre-Quaternary geological units. The samples were dried and sieved ( -80 mesh) at the field camp, later treated (drying, sieving, pulverization) in the Central Geological Laboratory in Ulaanbaatar and subsequently analysed in the Acme Analytical Laboratories, Vancouver, Canada. The basic set of 36 elements including $\mathrm{Au}$ (detection limit $0.2 \mathrm{ppb}$ ) was determined by ICP-MS after acid decomposition. A set of 232 samples was additionally analysed for Pt, $\mathrm{Pd}$ and $\mathrm{Rh}$ with Au by ICP-MS (15 g-splits to get a more representative analyses of these elements subject to nugget effect).

The data set of 1,222 stream-sediment analyses was statistically evaluated using MS Excel and a freeware programme for geochemical data plotting - GCDkit (Janoušek et al. 2006). The principal elemental associations were defined on the basis of upper coefficients of correlation for anomalous values and considering bedrock geology. The single-element distribution maps with delineated anomalous source areas of principal elemental associations were compiled and plotted on a scale 1:50,000 (ArcGIS software).

\subsection{Whole-rock geochemistry}

Whole-rock samples of selected petrographic types were collected during geological mapping to determine the geochemistry of individual geological formations. Lithogeochemical grab sampling was used during a detailed prospection in some specified and perspective areas to assess the contents of ore elements-indicators.

Major-element oxides, $\mathrm{C}$ and $\mathrm{S}$ were analysed by ICP-ES and trace elements including REE by ICP-MS (Groups 4B and 1DX) in ACME Labs. Loss on ignition (LOI) was determined after heating to $1000^{\circ} \mathrm{C}$. The data were processed by the GCDkit software (Janoušek et al. 2006). The bulk composition of the rocks in a given geo- logical unit was normalised to the average composition of the Continental Crust. Plotting using the box-and-whisker graphs to delineate formations that underwent hydrothermal processes/overprint (e.g. Reiman and Caritat 1998) was found particularly useful.

\subsection{Mineralogical study of gold and accom- panying heavy minerals}

The morphology and composition of gold grains in placer deposits were studied to determine the nature of placer gold, which could serve as an indicator in search for the source area, and the setting of primary mineral deposit (Malec 2007). The gold grains were examined under a stereoscopic microscope and photographed using the electron microscope CamScan 3200 in the X-ray Microanalysis Facility (LAREM) of the Czech Geological Survey in Prague. Besides the morphology were tested the presence of secondary coatings of pure gold and their thickness and porosity. The composition of grain surface and of single gold particles in polished sections was analyzed by the energy dispersive microanalyzer (EDS) Link ISIS manufactured by Oxford Instruments. The minerals intergrown with gold were identified by the same procedure. Polished sections were prepared after embedding gold grains into epoxy resin. The polished specimens were examined under the ore microscope in order to recognize possible inhomogeneities (zoning, secondary coatings on pure $\mathrm{Au}$, inclusions or intergrowths).

The distance of placer gold particles from a primary source was estimated from their morphology, mechanical disturbances on the grain surface, presence and thickness of secondary coatings of pure gold, and from mineral intergrowths (see Morávek et al. 1992 for experience from the Bohemian Massif). The data on gold grain shape show a clear relationship to the distance of transport from the primary source as approved by the literature. For instance the effect of "hammering" causes the change in shape of fluvially transported gold grains and the attendant abrasion affects their surface texture (Knight et al. 1999; Youngson and Craw 1999).

\subsection{Ore mineral study}

Selected samples of vein, ore and gossan material collected during the geological mapping and reconnaissance tours were processed in the Laboratory of the Geological Research Center in Ulaanbaatar by standard petrography and ore microscopic methods. Some of thin and polished sections were studied in the Mineralogical Laboratory of the Czech Geological Survey in Prague, where also analyses of ore minerals by the Link ISIS were carried out. 


\section{Results}

\subsection{Distribution and character of gold in intermittent streams}

Gold is distributed very irregularly in the surveyed area as seen on the maps of heavy mineral concentrate (HMC) and stream-sediment geochemistry (Hanžl and Aichler 2007). Alluvial gold was found more commonly in the areas with exposed rocks of the Khan Taishir Fm. Isolated alluvial gold indications were identified also in other Neoproterozoic crystalline complexes. Gold scarcely appeared also in the drainage sediments within the lowgrade to unmetamorphosed Palaeozoic and Mesozoic volcanosedimentary formations. Occurrences of placer gold associated with Mesozoic clastic sediments were newly discovered in the Samoandamba Uul.

Taken together, gold was determined in 175 of 2,500 collected HMC samples. The size of gold grains varies from dust to $0.2-1 \mathrm{~mm}$ across or to small nuggets. Its colour is always gold-yellow with metallic lustre. The shape of alluvial gold grains is variable and depends on the origin as well as the length of transport as is documented by results of morphological study (Fig. 2).

Short transport of gold particles corresponding to hundreds of metres is characteristic of gold from the Erdene Uul (map sheet L-47-89V) and the Ovoot am $(\mathrm{L}-47-101 \mathrm{G})$. Gold from the Unegt Uul-W area (L-47-101G) is interpreted to have undergone a longer transport $(\sim 1.5 \mathrm{~km})$. For gold from Samoandamba (L-47-89B) and Ulaan Uul-E (L-47-101B) areas, a transport in the order of several kilometres is assumed. In the case of placer gold from Neogene alluvial terraces in Bayan Tolgoi (L-47-89G), it might have been even longer.

Placer gold from the studied localities of the eastern Mongolian Altay has mostly a similar composition. In general, the gold is typically of a high fineness $(>900)$ and, except for minor Ag, devoid of any other admixture. A small amount of gold grains of a lower fineness was found in Erdene Uul, in the samples from the Neogene alluvial terrace sediments (L-47-89G) and Ovoot am area
(L-47-101G). A more detailed treatment of the placer gold morphology and composition is a part of descriptions of some selected localities in the Chapter 4.3.

\subsection{Gold-bearing mineralizations}

The presence of primary gold-bearing mineralizations was indicated by clastic gold in the heavy mineral concentrates and by Au contents in stream sediments. In the course of the reconnaissance studies some showings of gold-bearing mineralizations were found, which several are considered to be of a potential economic importance. The distribution of gold-bearing occurrences is shown in the Fig. 1.

The following types of Au-bearing mineralizations were discovered in the studied area:

- $\mathrm{Au}$ and $\mathrm{Au}-(\mathrm{Ag}, \mathrm{Cu})$ quartz veins in crystalline complexes,

- Au-(Ag) quartz veins in Permian mafic volcanic rocks,

- gold-bearing base metal quartz-carbonate veins,

- other showings of gold-bearing mineralizations,

- gold placers.

\subsubsection{Au and $\mathrm{Au}-(\mathrm{Ag}, \mathrm{Cu})$ quartz vein mine- ralizations}

Gold-bearing mineralization of this type is associated almost exclusively with the rocks of the Khan Taishir $\mathrm{Fm}$. The formation was defined and assigned to the Neoproterozoic (Vendian according to Markova 1975) in the Khan Taishir Mts. ridge south of the Altay town. Presently the formation is considered to be of Vendian-Cambrian age (Dergunov 2001), as confirmed by radiometric dating (Badarch et al. 2002; Khain et al. 2003). Geological, petrographic and geochemical data from the Khan Taishir Fm. point to a dismembered ophiolite sequence (Hanžl and Aichler 2007) with prevailing basaltic volcanic rocks, sporadic deep-water sediments and boudins of serpentinites. This accords with Zonenshain and Kuzmin (1978), who described the ophiolite association in the Khan Taishir Massif.

Fig. 2 Morphology and internal structures of placer gold grains from the eastern Mongolian Altay. on the Fig. 2a, SEI; c - isometric grain with a moderately worked surface, SEI; d - plate of gold with slightly worked surface, SEI; e - oblong irregular gold grain with a very slightly modified morphology, SEI; f - irregular slightly worked forked gold, SEI; $\mathbf{g}$ - flat, irregular, moderately worked gold grain with rests of clay and limonite on the surface, SEI; $\mathbf{h}$ - intergrowths of gold (admixture of 6.9 wt. \% Ag; bright) with albite and quartz (dark), polished section, BEI; i - inclusion of digenite with bornite (dark) in gold containing 5.6 wt. \% Ag (light grey), polished section, BEI. Alluvial sediments, Ovoot Am area, L-47-101-G: j - flat slightly worked gold grain with admixture of 14.2 wt. \% Ag, SEI.

Neogene alluvial terrace sediments, Bayan Tolgoi area, L-47-101G: $\mathbf{k}$ - rounded flake of gold with a strongly modified shape, SEI; $\mathbf{l}$ - detail of the surface of the gold flake on the Fig. 2k, SEI.

Alluvial sediments, Unegt Uul-W area, L-47-101G: $\mathbf{m}$ - flat and intensively worked gold grain, SEI.

Quaternary sediments, Unegt Uul-SEE area, L-47-101B: n - isometric gold grain with a slightly modified morphology, SEI; o - flat gold nuggets, photomicrograph.

$(\mathrm{SEI}=$ secondary electron image; $\mathrm{BEI}=$ backscattered electron image $)$ 

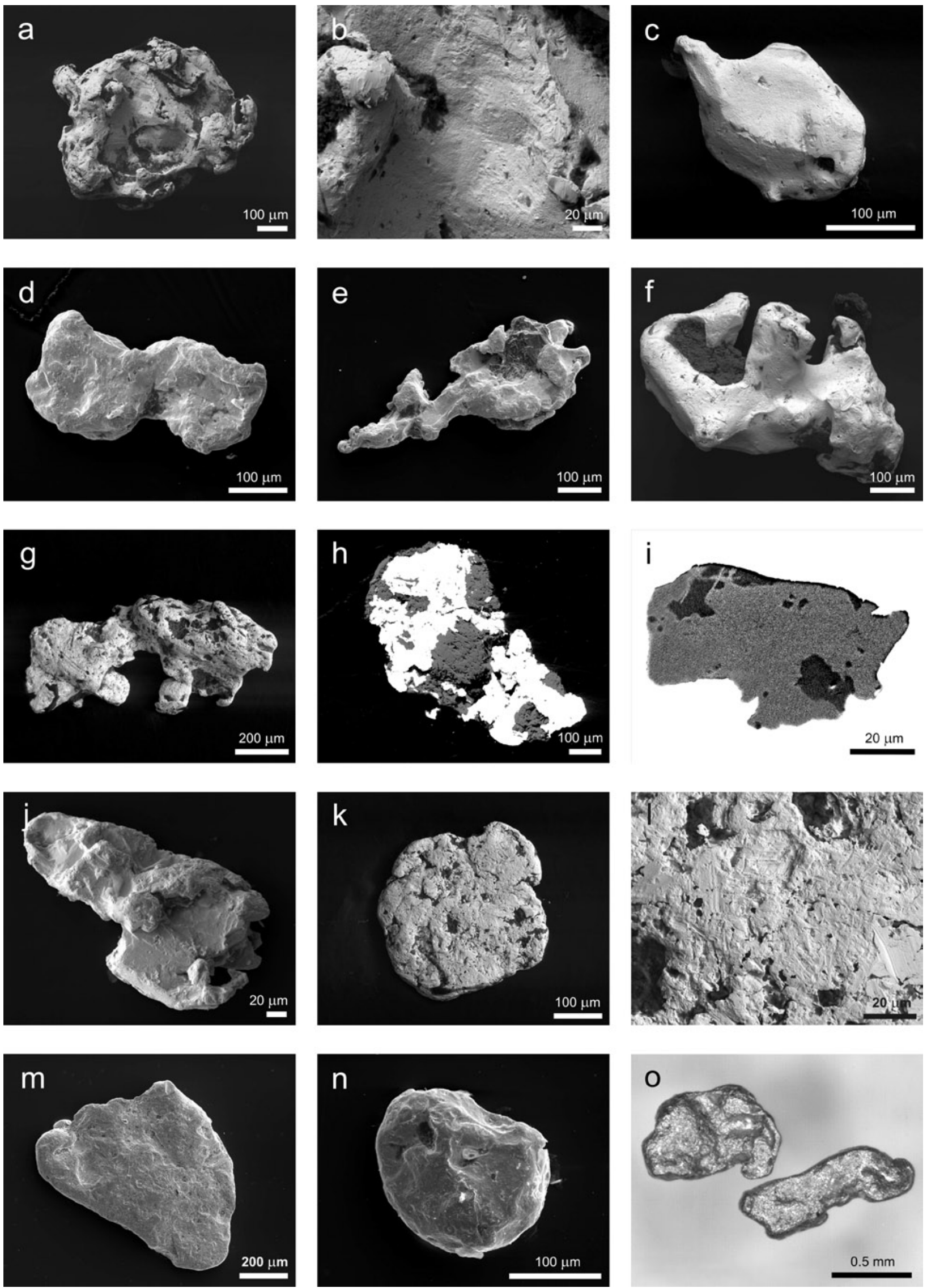
The Khan Taishir Fm. occurs in two regions in the surveyed territory. The larger one is exposed $\mathrm{E}$ and $\mathrm{SE}$ of the Erdene Uul Mt. in the NW part. Small exposures crop out in erosion windows at the footwall of the Permian rocks in the Khar Argalantyn Nuruu Mts. in the E part of the region. The Khan Taishir Fm. has been thrusted from the north over the Alag Khadny and Zamtyn Nuruu crystalline complexes.

The Au-quartz vein type showing related to the Khan Taishir Fm. was discovered namely on the SE slopes of the Erdene Uul Mt. (L-47-89V, Fig. 3). The local rock association represents a nearly complete ophiolite sequence (Perfiliev and Kheraskov 1980) dominated by various types of metabasalts, gabbros, green schists and agglomerate tuffs enclosing lenses of limestones. The

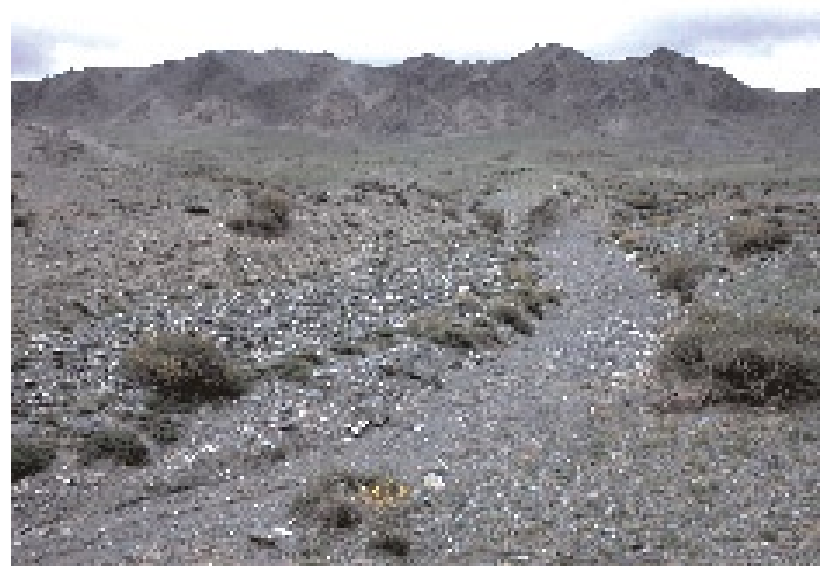

Fig. 3 The Erdene Uul Mt. range, viewed from the south. ophiolite sequence was intruded by tonalites and all the rocks were metamorphosed under the greenschist facies conditions (Fig. 4).

The $\mathrm{Au}$ and $\mathrm{Au}-(\mathrm{Ag}, \mathrm{Cu})$ quartz \pm carbonate veins and veinlets have tabular to lenticular shapes and form enechelon sets of lenses mostly parallel with the foliation dipping to the SW or WSW (Fig. 5). The veins outcropping on the tops of local rocky ridges are flat or mildly inclined filling extensional fractures. All the veins have the lengths of several to 10-20 metres and occur isolated or in en-echelon sets. Their thickness varies from 10 to $50 \mathrm{~cm}$ and does not exceed $1.5 \mathrm{~m}$. Gold grade varies from traces to first $\mathrm{g} / \mathrm{t}$ of $\mathrm{Au}$.

The veins are dominated by white to grey-white medium-grained quartz, with a lesser amount of carbonates and albite. Ore mineral association is formed by pyrite, less commonly by chalcopyrite, pyrrhotite, malachite, goethite, hydrogoethite and gold. Sericitization, carbonatization and pyritization (Fig. 5) are the typical wall-rock alterations (forming aureoles $0 . \mathrm{X}$ to $2-3 \mathrm{~m}$ thick around the veins).

Native gold forms minute grains, mostly of an irregular shape but also more or less isometric or flat, as described from HMC samples taken from alluvial sediments in the mountain valleys and from alluvial fans beneath the outcrop areas. Quartz, albite, K-feldspar, hornblende(?), clinopyroxene(?), chlorite, biotite, Tioxide (rutile), limonite, sporadically also pyrite, digenite and bornite were found in form inclusions or intergrowths with gold (Fig. 2h-i). The fineness of gold ranges from 750 to 1,000 , the majority of values fluctuating between 900 and 950 (median 920). This means that the gold of a low purity is rare.

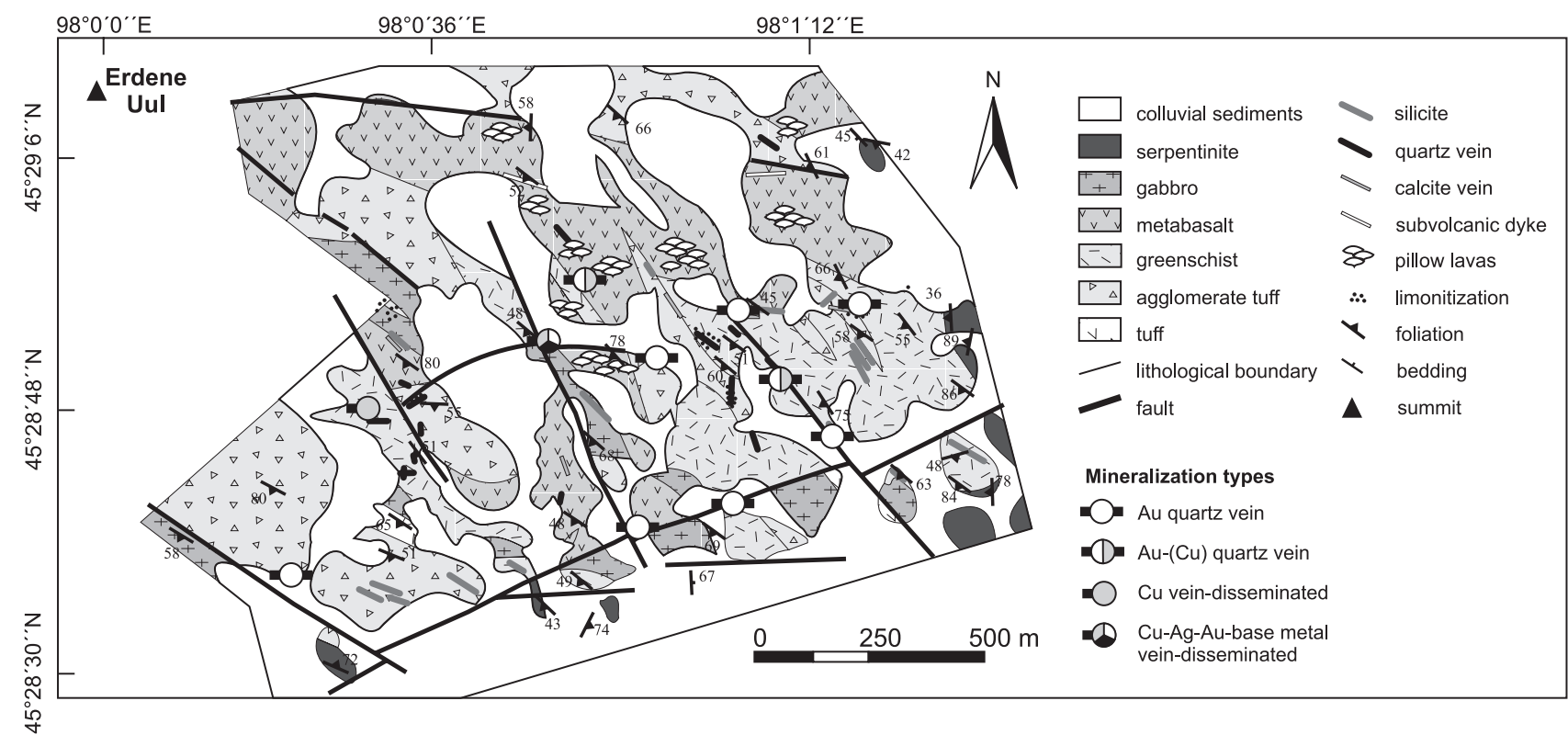

Fig. 4 Geological sketch of the Erdene Uul prospective area. 


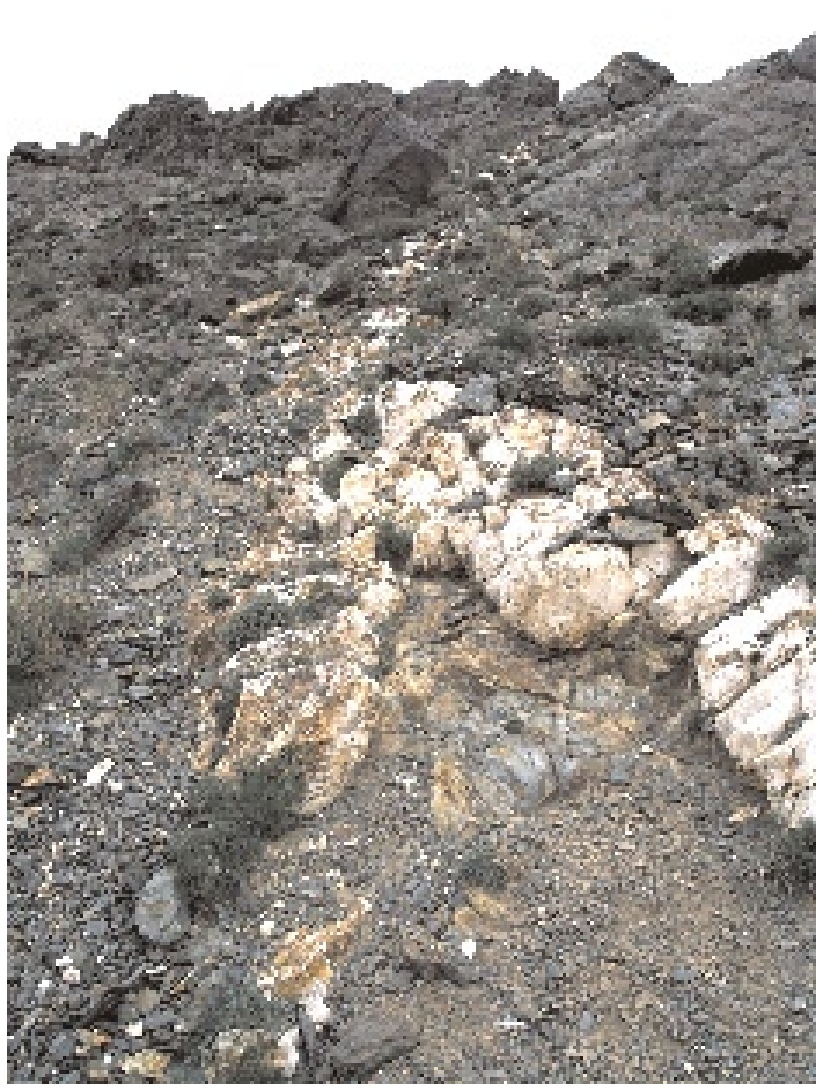

Fig. 5 Gold-bearing quartz vein arranged en-echelon to the foliation of the host basalt metatuffs and accompanied by wall-rock alteration, Erdene Uul Mt. area.

The composition and the character of gold-bearing veins and the high fineness of gold support the likely hydrothermal-metamorphic origin of the gold mineralization. The element distribution in the rocks of the Khan Taishir Fm. characterized by anomalous concentration of $\mathrm{Au}, \mathrm{Cu}$ and other ore elements (Fig. 6) may suggest an important role for hydrothermal processes during its metamorphic development.

\subsubsection{Au-(Ag) quartz mineralization}

The occurrences of $\mathrm{Au}-(\mathrm{Ag})$ quartz vein mineralization were found in Permian volcanic rocks on the northern slopes of the Khar Argalantyn Nuruu Mts. (L-47-90A).

Three volcanic and volcanoclastic formations of a continental origin were recognised. The Khar Argalantyn Fm. was originally designated by Borzakovskii et al. (1985) as a Lower Permian complex. The Delger Khangay Fm. was firstly described by Mosiondze (in Zabotkin et al. 1983) as a Upper Permian complex and reclassified to Lower Permian as was the Khov Fm. occurring along the southern part of the Lake Terrane (Hanžl and Aichler

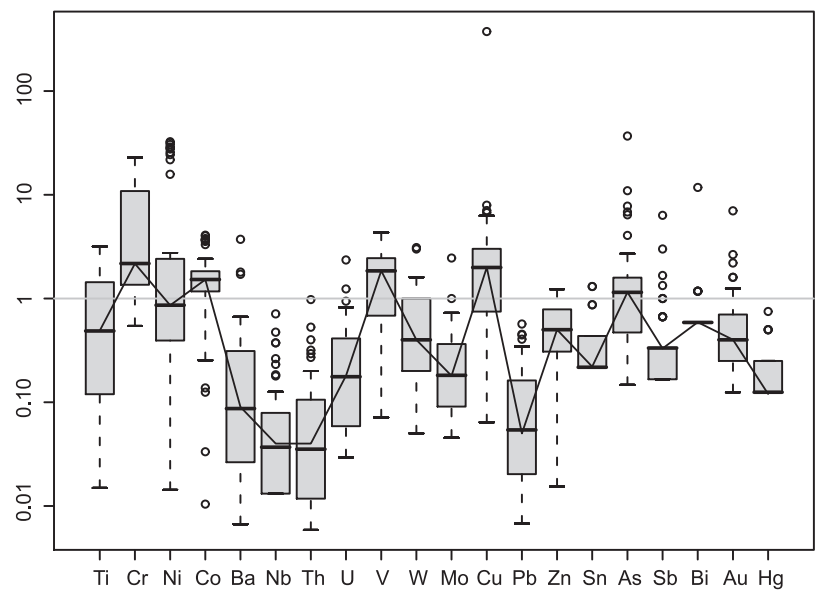

Fig. 6 Bulk chemistry of the Khan Taishir Fm. rocks. Normalization values (bulk continental crust) according to Reiman and Caritat (1998). For each element, the box represents $50 \%$ of the population (limited by two quartiles); the horizontal line inside is the median and the "whiskers" show the total range without outliers denoted by small circles (Janoušek et al. 2006).

2007). Nevertheless, all Permian volcanic rocks are of a similar age and share analogous geochemical character in this part of the Lake Terrane. They appear to represent various products of lateral variations in subaerial volcanic activity including lava flows, agglomerates, ignimbrites, tuffs and continental volcanoclastic sediments. The major-element data from the Permian volcanic rocks show a compositional variation from rhyolite, trachydacite and trachyte to trachyandesite and trachybasalt. Except for rhyolites, these volcanic rocks have an alkaline affinity (Hanžl and Aichler 2007).

The $\mathrm{Au}-(\mathrm{Ag})$ quartz veins were observed east of the Khuren Ondor Uul Mt. (L-47-90A). They are associated with the Permian volcanic rocks of the Delger Khangay Fm. being composed of trachytic andesites, basaltic andesite and subordinate basalts, rhyolites and their tuffs. Irregularly distributed gold-bearing veins are north of the contact with the Lower Permian Shar Oroy Massif built by reddish medium- to coarse-grained granites-granodiorites. The field relations along the contact of the granites with volcanic rocks of the Delger Khangay Fm. suggest a cogenetic relationship. Veins of white-grey quartz and quartzcarbonate lenses and silicified zones do not exceed 0.X m in thickness and several metres in length. In addition to quartz and carbonates they contain mostly pyrite, chlorite, and traces of malachite. The grade of sampled veins varies from 0.X to first ppm Au. Magnetite with disseminated $\mathrm{Cu}$-mineralization (chalcopyrite, chalcocite, covelline, malachite) and disseminated stibnite are common in mafic volcanic rocks in the vicinity of gold-bearing veins. 


\subsubsection{Au-Cu-Ag base metal mineralization}

Occurrences of auriferous base metal veins and disseminated mineralization were found in exposures of the Khan Taishir and Maykhan Tsakhir formations in the Lake Terrane and of Tugrug Fm. in the Gobi Altay Terrane.

A mineralized NNE-SSW trending zone was ascertained in the central part of a block built by the Khan Taishir Fm. southwest of the Ukher Schuldag Uul. The zone, 3-10 m thick and $140 \mathrm{~m}$ long, occurs in cracked basalt metatuffs. The rocks are limonitized and bleached having ochre-yellow to brown-yellow colours. Limonitized quartz-carbonate veins and stringers carrying sulphides, common pyrite impregnations and large gossan are present here. In such massive gossans with increased contents of $\mathrm{Au}, \mathrm{Ag}, \mathrm{Cu}$, and $\mathrm{Pd}$, native gold, pyrite, goethite, hydrogoethite and scarce native copper were identified in polished sections (Fig. 7).

The existence of a mineralized zone was indicated by elevated $\mathrm{Au}$ contents in stream sediments. The absence of alluvial clastic gold in HMC samples indicates that probably only fine gold-bearing sulphidic mineralization can be expected in this area.

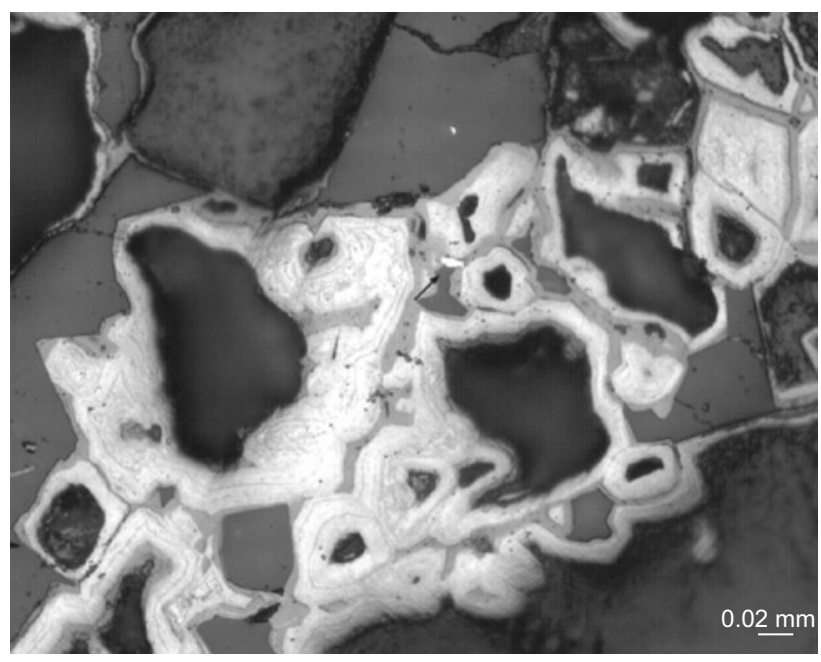

Fig. 7 Tiny gold grain (white indicated by black arrow) in the goethite-hydrogoethite (light) gossan layer, accompanied by quartz (dark grey). Photomicrograph of the polished section, reflected light. Ukher Schuldag Uul-SW.

Exceptionally, metal-rich samples of gossan above a gold-bearing base metal quartz-carbonate vein $20 \mathrm{~cm}$ thick and of an unknown length was discovered in a local slope cut (15.39 g/t Au, 61.1 g/t Ag, $25 \mathrm{ppb} \mathrm{Pd})$. Similar limonitized zones with quartz-carbonate veins and veinlets with common disseminated pyrite in the altered wall rocks were described also in the northern parts of the Khan Taishir Fm. (L-47-89V). These are mostly E-W striking. However, the reconnaissance samples taken from these zones did not yield increased gold contents.

An occurrence of $\mathrm{Au}-\mathrm{Cu}$ mineralization was also found in a swarm of limonitized $10-20 \mathrm{~cm}$ thick quartz-carbonate veins/lenses hosted by chloritized and limonitized andesite-basalt metatuffs in the surroundings of the Khanangiin Khokh Uul (L-47-89V). The width of a N-S trending zone is $c .15 \mathrm{~m}$ and the length exceeds $150 \mathrm{~m}$. Its mineralization was indicated by increased gold contents in stream sediments.

Showings of gold in association with base metal $(\mathrm{Cu}$, $\mathrm{As}, \mathrm{Zn}, \mathrm{Pb}, \mathrm{Ag}$ ) veins were ascertained in the Cambrian Tugrug Fm. composed of siliceous chlorite-sericite schists with intercalations of greenschists and quartzites $\mathrm{N}$ and NW of the Khar Khayrkhan Uul (L-47-101A). Low content of $\mathrm{Au}$ and elevated contents of silver were found in a quartz vein in silicified limestones of the Maykhan Tsakhir Fm. in the Tuymert Tsakhir Tolgoi area (L-47-89V). Tetrahedrite, covellite, malachite, azurite and antimony oxides were identified among ore minerals.

\subsubsection{Other showings of gold-bearing mine- ralization}

Gold in the HMC samples or increased contents of $\mathrm{Au}$ in stream sediments were detected also in other geological formations within the surveyed territory. However, their primary sources could not be identified.

Gobi Altay Terrane. Geochemical mapping only sporadically showed scattered Au anomalies indicating most likely local occurrences of gold-bearing quartz \pm carbonate vein/veinlet mineralizations associated with the Ordovician (Bayan Tsagaan Fm.), Devonian (Gichigeney Fm.) and Carboniferous (Tsokhoriin Nuruu Fm.) rocks in the Gichigeney Nuruu Mts. (L-47-101G).

Quartz veins and/or silicified zones with pyrite in chlorite schists and greenschists of the Ordovician Bayan Tsagaan Fm. are proposed to be a possible primary source of alluvial gold in the Ovoot am area (L-47-101G). Two flat gold grains with a different fineness ( 980 and 860$)$ intergrown with chlorite and accompanied by pyrite and barite were studied. Their morphology reflects a short transport, with a distance not exceeding several hundreds of metres (Fig. 2j).

A gold grain $(\sim 0.2 \mathrm{~mm})$ studied from the area $\mathrm{W}$ of the Unegt Uul Mt. (L-47-101B) is slightly to moderately mechanically worked (Fig. 2m), isometric and likely of high purity ( $\sim 990$ according to its surface analysis). Calcite was identified in the intergrowths. The length of transport can be estimated from several hundreds of metres to about $1.5 \mathrm{~km}$. The gold probably originated from calcite-quartz veins associated with the granites of the Unegt Uul Crystalline Complex. 
Lake Terrane. Besides the Erdene Uul region, other potential areas of gold-bearing mineralization were determined in the Lake Terrane. Gold found by geochemical mapping indicates also local occurrence of Au-mineralizations in other areas of the Khan Taishir Fm. (L-47$89 \mathrm{~V}, \mathrm{G}, 90 \mathrm{~A})$. Low sulphide quartz-carbonate veins are considered as the likely source of clastic gold. On the contrary, fine gold detected in stream sediments comes probably from gold-bearing base-metal vein(s) and/or disseminated mineralization.

The origin of unique clastic gold in the Zamtyn Nuruu Crystalline Complex (L-47-89V, G) can be related either to quartz veins with base metal sulphides hosted by gneisses, amphibolites and calc-silicate rocks, or if associated with scheelite, to quartz veins in mica schists.

Solitary occurrence of alluvial gold north of the Khuren Undur Uul Mt. accompanied by scheelite, pyrite and barite may have been derived from quartz veins, locally with common magnetite, confined to the granites of the Shar Oroy Massif (L-47-90A).

The presence of $\mathrm{Au}$ together with other elementsindicators $(\mathrm{As}, \mathrm{Sb}, \mathrm{Hg})$ detected in stream sediments shows the occurrence of $\mathrm{As}-\mathrm{Sb}-\mathrm{Hg}( \pm \mathrm{Pb}-\mathrm{Zn})$ vein or disseminated mineralization confined to the $\mathrm{E}-\mathrm{W}$ trending zone in cracked acid volcanic rocks of the Permian Khar Argalantyn Fm. (L-47-90G).

\subsection{Gold placers}

Gold placers are scarce in the studied area and the observed contents of gold in Neogene terrace and Quaternary alluvial sediments are mostly low and irregular. A prospective occurrence of gold in Mesozoic conglomerates and sandstones was discovered in the northern part of the Zamtyn Nuruu area.

\subsubsection{Erdene Uul-S}

Gold placers in alluvial sediments are known from the southern slopes of the Erdene Uul Mt. (L-47-89V, Fig. 8). A slight change in morphology of gold grains with a size ranging from 0.2 to $2.5 \mathrm{~mm}$ and only an exceptional secondary coating testify for a short transport. Their shapes are mostly irregular, but also more or less isometric and sometimes flat; the crystal planes are abundant, as well. The fineness of gold fluctuates mostly between 900 and 950. Frequent intergrowths of gold with rock-forming minerals (quartz, albite, chlorite etc.) reflect the character of the primary mineralization, i.e. metamorphic sulphide-poor quartz veins and/or veinlets. These occur in the rocks of the Khan Taishir Fm. exposed in the Erdene Uul mountain range above the placer (see Chapter 4.1). The distribution of gold in alluvial sediments is very irregular. The Erdene Uul placer represents an intact alluvial placer of a small extent and low potential, which is occasionally exploited by the local illegal miners.

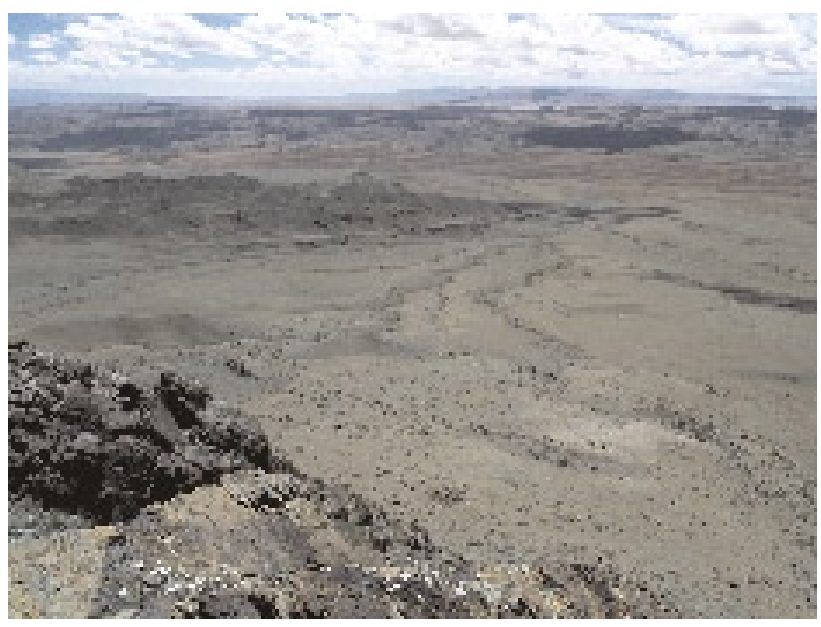

Fig. 8 View of alluvial fans on the southern slopes of the Erdene Uul Mt.

\subsubsection{Ulaan Uul-SEE}

The source of placer gold from intermittent streams was traced in the southern slopes of the Ulaan Uul range SEE of the Unegt Uul Mt. (L-47-101B). The gold grain features (such as morphology and fineness of surficial parts corresponding to $\sim 1,000$ ) indicate a transport over a distance in an order of few kilometres (Fig. 2d-e). An erosional remnant of Quaternary sediments of alluvial fans (sands and silty sands) on an ancient peneplain surface was identified as the source of the scarce gold.

\subsubsection{Neogene terrace sediments, Bayan Tolgoi}

Traces of placer gold accompanied by barite, pyrite and common titanite were identified in gravels and sands of large Neogene terraces of the Oshin Fm. and of Quaternary drainage sediments in Bayan Tolgoi (L-47-89G). The morphology of strongly reworked flat gold grains and the presence of surficial films of secondary enriched $\mathrm{Au}$ (Fig. 2k-1) indicate a long transport estimated at several to tens of kilometres. The varying fineness $(1,000,934$ and 802) may imply two distinct primary sources of gold, i.e. hydrothermal and/or metamorphogenic veins confined to tectonic zones in crystalline complexes, or subvolcanic ore deposits.

\subsubsection{Mesozoic sediments}

A prospective occurrence of placer gold in the Mesozoic sediments was newly discovered in the northern part of 
the Zamtyn Nuruu representing a conglomerate-hosted clastic Au type (Dejidmaa et al. 2005).

Mesozoic sequences in the studied area are represented by continental sediments and volcanic rocks of the Late Jurassic-Early Cretaceous ages that developed in a rift regime (Yarmolyuk 1983). Mesozoic sediments are divided into four formations: Toromkhon, Undurukhin, Anaday Khudag and Khulsan Gol (Rauzer et al. 1987).

The Toromkhon Fm. is the lowermost Mesozoic sequence. The contact with the underlying Neoproterozoic/Palaeozoic rocks is transgressive. Sediments of the Toromkhon Fm. consist of poorly to extremely poorly sorted conglomerates, breccias and sandy conglomerates with rare siltstone horizons. Poorly sorted and subangular clasts in massive conglomerates without grading indicate rapid deposition in arid/semiarid conditions. The degree of lithification is relatively low and thus they are interpreted as sediments of proximal facies of alluvial fans (Gilíková et al. 2007).

The sediments of the Undurukhin Fm. form up to $13 \mathrm{~m}$ thick cycles consisting of conglomerates fining upwards into sandstones, mudstones and marls. There are frequent wash-outs at the base of these cycles. Contact with the Toromkhon Fm. at the footwall is transitional with local wash-outs. The colour of sediments changes from red-brown to ochre-brown up to greenish brown-yellow shades. The grain size decreases upwards similarly to consolidation and degree of sorting in sediments. Bedding is monoclinal, gently dipping to the NW.

Irregularly dispersed gold was found in the profile of clastic sediments of both the Toromkhon and Undurukhin formations and in alluvial sediments of erosion furrows and valleys north of the Samoandamba Uul Mt. (Fig. 9) on map sheet L-47-89B. Mesozoic sediments

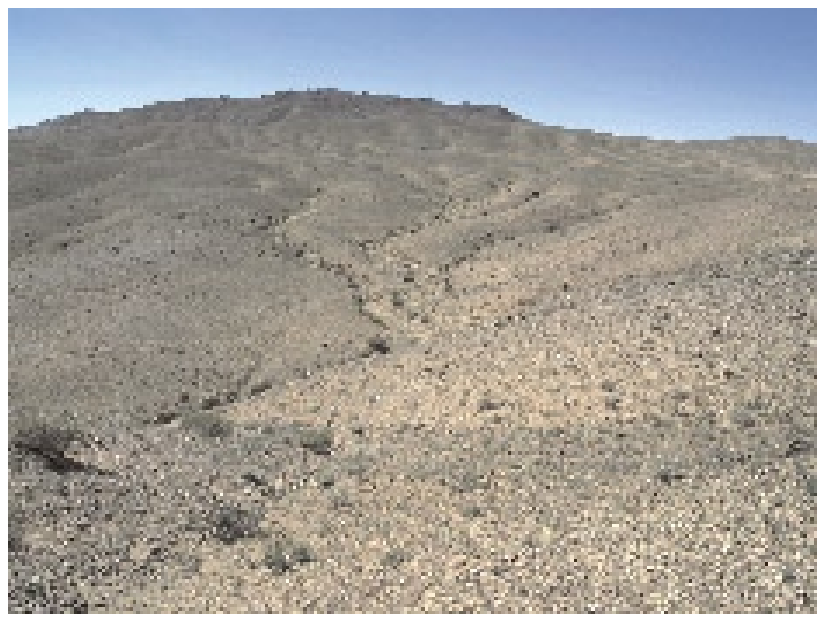

Fig. 9 The central part of the gold placer in Mesozoic/Quaternary sediments north of the Samoandamba Uul Mt. (top of the horizon). are underlain by Permian volcanic sequence (rhyolites, trachydacite, trachybasalts and their tuffs).

Gold released from Mesozoic sediments concentrates at the bottom of erosion furrows being lodged in crevices in the bedrock composed of sandstone benches or thresholds built by Permian volcanic rocks. The size of gold grains from these intermittent streams varies from 0.2 to $3.5 \mathrm{~mm}$ (Fig. 10), but nuggets exceeding $10 \mathrm{~mm}$ were also found (Fig. 10i). The morphology of grains was moderately to strongly affected by rounding and/or surface scratching. The flat shapes of gold grains prevail but isometric and irregular shapes are also relatively common. The distance of transport was estimated at a few kilometres but their re-deposition from older sediments cannot be excluded. The panned-concentrate sampling showed that the gold is accompanied by magnetite, ilmenite, chromite, and minor cassiterite with cinnabar.

The fineness of gold ranges between 950 and 1,000, occasionally reaching 900-950 (median 998). The coatings of secondarily enriched $\mathrm{Au}$ were found in case of gold particles with fineness of about 960 or less. Inhomogeneous internal structures - small domains with sharp outlines, irregular or lobate exsolutions of gold with distinctly enhanced $\mathrm{Ag}$ contents - were observed in some gold grains and nuggets (Fig. $10 \mathrm{j}-\mathrm{k}$ ). These textures may represent two or more generations of gold, or more likely products of recrystallization during diagenesis of sediments and/or weathering of primary occurrences. Inclusions of quartz, muscovite, K-feldspar and calcite were found in bigger gold grains (Fig. 101) but it is not clear whether they represent intergrowths or were squeezed into the grains. On the other hand, small gold particles are free of inclusions or intergrown minerals.

Primary sources of gold are supposed to be most likely uniform, probably belonging to hydrothermal or metamorphic veins in crystalline complexes of the Khan Taishir Fm. Less likely source represent Permian volcanics, as is also documented by the petrography of clasts in Mesozoic sediments.

Gold is less abundant and irregularly distributed in Mesozoic sediments but their volume is enormous. The base of these sediments was determined at a depth of about $280 \mathrm{~m}$ by the geophysical methods (VES and reflection seismic profiling) at the northern contact with the Permian volcanic rocks (Valtr 2007). The E-W zone north of the Samoandamba Uul Mt. with outcropping sediments of the Toromkhon and Undurukhin formations was recommended for a detailed follow up exploration. Moreover, it is worth noting that these Mesozoic sedimentary sequences and their erosional remnants are known from other parts in the north of the surveyed area (Hanžl and Aichler 2007). 

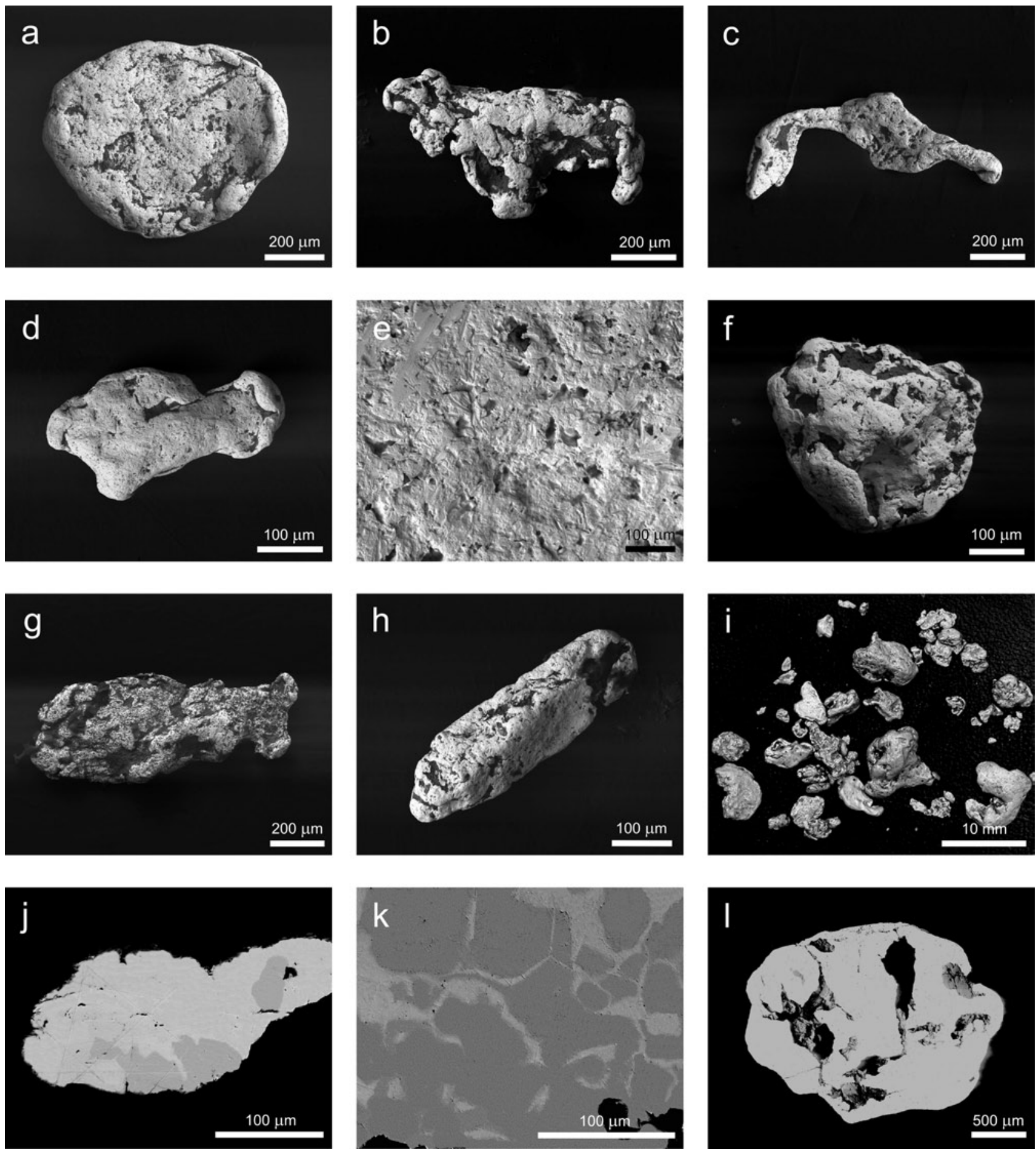

Fig. 10 Morphology and internal structures of placer gold grains from the Samoandamba-N area, L-47-89-B: a - intensively worked and rounded flake of pure gold indicative of a long transport, SEI; $\mathbf{b}$ - irregular flat and moderately worked gold grain, SEI; $\mathbf{c}-$ oblong moderately worked gold grain, SEI; $\mathbf{d}$ - flat, rounded, and moderately worked gold grain, SEI; e - detail of the surface of the gold particle on the Fig. 10e, SEI; f - isometric alluvial gold grain with slightly modified morphology, SEI; $\mathbf{g}$ - moderately worked flat gold grain, SEI; h - slightly worked oblong crystal of gold, SEI; $\mathbf{i}$ - gold nuggets from alluvial sediments, macro photo; $\mathbf{j}$ - polished section of an irregular gold grain; small domains of gold with admixture of 7.8 wt. \% Ag (dark) in pure gold (bright), BEI; $\mathbf{k}$ - polished section of a flat nugget; small fields of gold containing $9.2 \mathrm{wt} \%$ of Ag (dark) in pure gold (bright) represent probably recrystallization products, BEI; l - polished section of a nugget with inclusions of muscovite, K-feldspar, quartz, and calcite, BEI. (SEI = secondary electron image; $\mathrm{BEI}=$ backscattered electron image). 


\section{Conclusions}

The area of about $4,000 \mathrm{~km}^{2}$ in the eastern part of the Mongolian Altay Mts. region was mapped on a scale of 1:50,000 in the framework of the International Development Cooperation of the Czech Republic in 2004-2006. Regional geochemical mapping involved the panned heavymineral survey, geochemistry of dry stream-sediments from intermitent streams and whole-rock lithogeochemistry.

- The morphologies and compositions of placer gold grains were studied as a length of transport indicator, and in order to constrain the possible source of auriferous mineralizations. The gold with fineness over 900 and free of other impurities (except for Ag) is characteristic of the studied area.

- New occurrences and indices of $\mathrm{Au}, \mathrm{Ag}, \mathrm{Cu}, \mathrm{Zn}, \mathrm{Pb}$ and (Ba)-As-Sb-Hg mineralizations were discovered in some of the prospective areas.

- The surveyed part of the Lake Terrane has a potential for finding an economic gold-bearing mineralization.

- The Neoproterozoic Khan Taishir Fm. is supposed to host locally $\mathrm{Au}$ and $\mathrm{Au}-(\mathrm{Cu})$ veins and gold-bearing base metal vein-disseminated mineralization bound to metamorphosed (greenschist-facies) basic volcanic sequences.

- The Au-(Ag) quartz veins hosted by basic volcanic rocks of the Lower Permian Delger Khangay Fm. were ascertained in the area of the Khar Argalantyn Nuruu Mts.

- Low gold contents accompany also the As-Sb-Hg-(Ba) vein-disseminated mineralization confined to acid volcanic rocks of the Permian Khar Argalantyn Fm. The Ag-rich base metal quartz veins occur in silicified marbles of the Neoproterozoic-Palaeozoic Maykhan Tsakhir Fm.

- No prospective ore indications were found in the crystalline rocks of the Zamtyn Nuruu and Alag Khadny crystalline complexes or related to undifferentiated Palaeozoic plutonic rock bodies.

- In the Gobi Altay Terrane, the occurrences and showings of slightly auriferous base metal $(\mathrm{Cu}, \mathrm{As}, \mathrm{Zn}, \mathrm{Pb}$, $\mathrm{Ag}$ ) veins were ascertained in siliceous chlorite-sericite schists with layers of greenschists and quartzites of the Cambrian Tugrug Fm.

- Sporadic discontinuous Au anomalies indicate more likely only indications of auriferous vein mineralizations bound to the Ordovician (Bayan Tsagaan Fm.), Devonian (Gichigeney Fm.) and Carboniferous (Tsokhoriin Nuruu Fm.) rock sequences.

- Gold placers associated with the Upper Jurassic/ Lower Cretaceous, Neogene and Quaternary sediments are not common. Only newly discovered placers confined to the Mesozoic conglomerates and sandstones in the Samoandamba area are supposed to have an economic potential.
Acknowledgments. The project was conducted by the Czech Geological Survey in a close cooperation with the Geological Information Centre of Mongolia and the Mineral Resources and Petroleum Authority of Mongolia (MRPAM). The authors warmly thank to all members of the Czech Zamtyn Nuruu-50 expedition for their assistance in field and sample processing, in particular to J. Holák and Z. Novotný. Special thanks are due to Kh. Gantumur, the former Chief Geologist of MRPAM for his support of project. K. Hrdličková is acknowledged for the technical assistance during preparation of the paper. O. Gerel and J. Zachariáš are thanked for helpful reviews; M. Štemprok is acknowledged for the careful editorial handling.

\section{References}

Badarch G, Cunningham WD, Windley BF (2002) A new Terrane subdivision for Mongolia: Implications for the Phanerozoic crustal growth of central Asia. J Asian Earth Sci 20: 87-100

BoRZAKOVSKII YA ET AL. (1985) Making of geological map and map of raw deposits of the western Mongolia ( $\mathrm{W}$ of meridian $102^{\circ}$ ) on the scale 1:500,000 with explanatory text. Period I, maps M-46B, L-47A, B, V, G. Zarubezhgeologia, Moscow

Cunningham WD, Windley BF, Dorjnamuaa D, BadamgaROv J, SAANDAR M (1996) A structural transect across the Mongolian Altai: active transpressional mountain building in central Asia, Tectonics 15: 142-156

DejidmaA G, BadARch G (2005) Summary of pre-accretionary and accretionary metallogenic belts of Mongolia. In: Seltmann R, Gerel O, Kirwin DJ (eds) Geodynamics and metallogeny of Mongolia with a special emphasis on copper and gold deposits. CERCAMS/NHM London, SEG-IAGOD Field Trip, 14-16 August 2005, $8^{\text {th }}$ Biennial SGA Meeting, pp 25-29

Dejidmaa G, Bujinlkham B, Evinuu A, Enkhtuya B, Ganbaatar T, Moenkh-Erdene N, Oyuntuya N (2001) Distribution map of deposits and occurrences in Mongolia (on the scale 1:1,000,000). MRPAM - Geological Information Center, Ulaanbaatar

Dejidmaa G, Dorjgotov D, Gerel O, Gotovsuren A (2005) Preliminary description of mineral deposit models (types) for Mongolia. In: Seltmann R, Gerel O, Kirwin DJ (eds) Geodynamics and Metallogeny of Mongolia with a Special Emphasis on Copper and Gold Deposits. CERCAMS/NHM London, SEG-IAGOD Field Trip, 14-16 August 2005, $8^{\text {th }}$ Biennial SGA Meeting, pp 31-52

Dergunov AB (2001) Tectonics, Magmatism, and Metallogeny of Mongolia. Routledge, London, pp 1-304

Economos R, Hanžl P, HrdličKová K, Buriánek D, Said LO, Gerdes A (in print) Geochemical and structural constraints on the magmatic history of the Chandman 
Massif of the eastern Mongolian Altay Range, SW Mongolia. J Geosci

FLETCHER WK (1997) Stream sediment geochemistry in today's exploration world. In: GubINs AG (ed) Proceedings of Exploration 97: Fourth Decennial International Conference on Mineral Exploration, pp 249-260

Gilíková H, Budil P, Čech S, Hanžl P, Otava J, Svobodová M, ZIEGLER V (2007): Cretaceous sediments of the Eastern part of the Mongolian Altay. In: Breiter K (ed) Proceedings of the $3^{\text {rd }}$ Meeting of the Czech Geological Society, Volary, 19-22 September 2007, pp 15 (in Czech)

HANŽL P, Aichler J (eds) (2007) Geological Survey of the Mongolian Altay at a scale of $1: 50,000$ (Zamtyn Nuruu $-50)$. Final report of the International Development Cooperation project of the Czech Republic. Czech Geological Survey, Brno \& MPRAM, Ulaanbaatar, pp 1-376

Hanžl P, Buriánek D, Hrdličková K, Aichler J, Gerdes A, BYAMBASUREN D (2007) Granitoid massifs of the Zamtyn Nuruu area, SW Mongolia. In: BREITER K (ed) Proceedings of the $3^{\text {rd }}$ Meeting of the Czech Geological Society, Volary, 19-22 September 2007, pp 27

Hendrix MS, Graham SS, Carroll AR, Sobel ER, Mc Knight CL, Schulein BJ, Wang Z (1992) Sedimentary record and climatic implications of recurrent deformation in the Tianshan: evidence from Mesozoic strata of the north Tarim, south Junggar and Turpan basins, northwest China. Geol Soc Am Bull 104: 53-79

JANOUŠEK V, FARROW CM, ERBAN V (2006) Interpretation of whole-rock geochemical data in igneous geochemistry: introducing Geochemical Data Toolkit (GCDkit). J Petrol 47: 1255-1259.

Khain EV, Bibikova EV, Salnikova EB, Kröner A, Gibsher AS, Didenko AN, Degtyarev KE, Fedotova AA (2003) The Palaeo-Asian ocean in the Neoproterozoic and Early Palaeozoic: new geochronologic data and palaeotectonic reconstructions. Precambr Res 122: 329-358

Knight JB, Morison SR, Mortensen JK (1999) The relationship between placer gold particle shape, rimming, and distance of fluvial transport as exemplified by gold from the Klondike District, Yukon Territory, Canada. Econ Geol 94: 635-648

Kovalenko VI, Yarmolyuk VV, Bogatikov OA (1995) Magmatism, Geodynamics and Metallogeny of Central Asia. Miko Commercial Herald Publishers, Moscow, pp 1-272

KREJČí Z, HANŽL P (2006) Geoscience data management - Mongolian Altay Project. In: Vernadsky SGM RAS: $3^{\text {rd }}$ International Conference GIS in Geology, Extended Abstracts, Russian-French Metallogenic Laboratory, Moscow, p 33-35

MALEC J (2007) Study of gold particles from the Zamtyn Nuruu and Mongolian Altay obtained during heavy mineral survey undertaken in the years 2004-2006. In: HANŽL P, Aichler J (eds) Geological Survey of the Mongolian
Altay at a scale of 1:50,000 (Zamtyn Nuruu - 50). Final report of the International Development Cooperation project of the Czech Republic. Czech Geological Survey, Brno \& MPRAM, Ulaanbaatar

Marinov NA, Zonenshain LP, BlagonRavov VA(eds) (1973) Geology of the People's Republic of Mongolia: Volume 1, Stratigraphy. Nedra Press, Moscow, pp 1-582

Markova NG (1975) Lower and Middle Palaeozoic Stratigraphy of the Western Mongolia. Nauka, Moscow (in Russian)

MorÁvek P et al (1992) Gold in the Bohemian Massif. Czech Geological Survey. Prague, pp 1-245 (in Czech)

Mossakovsky AA, RuZhentsev SV, SAMygin SG, KheraskoVA TN (1993) Central Asian fold belt: geodynamic evolution and history of formation. Geotectonics 6: 3-33

Nicols G (1999) Sedimentology and Stratigraphy. Blackwell Science Ltd, London, pp 1-355

Perfiliev AS, Kheraskov NN (1980) Diabase complexes and the origin of layering of Earth's crust: tectonic layering of the lithosphere. Nauka, Moscow, pp 64-104 (in Russian)

Rauzer AA, Zhanchiv DI, Golyakov VI, Ykhina IF, Ivanov IG, Tsukernik AB, Afonin VV, Smirnov IG, Bykhover VI, Kravtsev AV, Baatarkhuyag A, Skoryukin Mi, Khodikov IV, Mantsev NV, Okaemov SV, Mischin VA, ENKHSAJKHAN T (1987) Report on results of geological mapping on scale 1:200,000 in the south-western part of Mongolian Altay in 1983-1986, Mongolian National Republic. Tekhnoexport, Moscow, pp 1-352 (in Russian)

Reimann C, Caritat P de (1998) Chemical Elements in the Environment. Factsheets for the Geochemist and Environmental Scientist. Springer-Verlag, Berlin, pp 1-398

SENGÖr AMC (1984) The Cimmeride orogenic system and the tectonics of Eurasia. Geol Soc Am Spec Pap 195: pp 1-82

ShaANDAR P (2003): Geology and mineral resources of the Lake Zone. Mongolian Geoscientist 23: 18-19

TAPPonier P, Molnar P (1979) Active faulting and Cenozoic tectonics of the Tien Shan, Mongolia and Baykal region. J Geophys Res 84(B7): 3425-3459

VALTR V (2007) Geophysical prospection in Zamtyn Nuruu 2005-2006. In: HANŽL P, Aichler J (eds) Geological Survey of the Mongolian Altay at a scale of 1:50,000 (Zamtyn Nuruu - 50). Final report of the International Development Cooperation project of the Czech Republic. Czech Geological Survey, Brno \& MPRAM, Ulaanbaatar

Vassallo R, Jolivet M, Ritz JF, Braucher R, Larroque C, Sue C, Todbileg M, Javkhlanbold D (2007) Uplift age and rates of the Gurvan Bogd system (Gobi-Altay) by apatite fission track analysis. Earth Planet Sci Lett 259: 333-346

Windley BF, Alexeiev D, Xiao W, Kröner A, Badarch $G$ (2007): Tectonic models for accretion of the Central Asian Orogenic Belt. J Geol Soc, London 164: 31-47 
XIE X, WANG X (1991) Geochemical exploration for gold: a new approach to an old problem. J Geochem Explor 40: $25-48$

YANSHIN AL (ed) (1976) Map of Mesozoic and Cenozoic tectonics of the Mongolian People's Republic: 4 sheets, scale 1:15,000,000. USSR Academy of Sciences, Moscow

Yarmolyuk VV (1983) Late Palaeozoic Volcanism in the Continental Rift Structures of Central Asia. Nauka, Moscow, pp 1-198 (in Russian)

YARMOLYUK VV (1986) Characteristics of structural position of continental rift structures in Mongolia. Izv Akad Nauk SSSR, Ser geol 9: 3-15 (in Russian)
YoungSOn JH, CRAw D (1999) Variation in placer style, gold morphology, and gold particle behavior down gravel bed-load rivers; an example from the Shotover/ArrowKawarau-Clutha River system, Otago, New Zealand. Econ Geol 94: 615-633

ZABOtKIn LB ET AL. (1983) Report on results of geological mapping on scale 1:200,000 in the Central-Gobi region of Mongolian National Republic in 1979-1982. Moscow (in Russian)

Zonenshain LP, Kuzmin MI (1978) The Khan-Taischir ophiolitic complex of Western Mongolia, its petrology, origin and comparison with other ophiolitic complexes. Contrib Mineral Petrol 67: pp 95-109 